\title{
Efficiency of carbon dioxide storage and enhanced methane recovery in a high rank coal
}

DOI:

10.1021/acs.energyfuels.7b02402

\section{Document Version}

Accepted author manuscript

Link to publication record in Manchester Research Explorer

\section{Citation for published version (APA):}

Hadi Mosleh, M., Sedighi, M., Vardon, P. J., \& Turner, M. (2017). Efficiency of carbon dioxide storage and enhanced methane recovery in a high rank coal. Energy \& Fuels. https://doi.org/10.1021/acs.energyfuels.7b02402

\section{Published in:}

Energy \& Fuels

\section{Citing this paper}

Please note that where the full-text provided on Manchester Research Explorer is the Author Accepted Manuscript or Proof version this may differ from the final Published version. If citing, it is advised that you check and use the publisher's definitive version.

\section{General rights}

Copyright and moral rights for the publications made accessible in the Research Explorer are retained by the authors and/or other copyright owners and it is a condition of accessing publications that users recognise and abide by the legal requirements associated with these rights.

\section{Takedown policy}

If you believe that this document breaches copyright please refer to the University of Manchester's Takedown Procedures [http://man.ac.uk/04Y6Bo] or contact uml.scholarlycommunications@manchester.ac.uk providing relevant details, so we can investigate your claim.

\section{OPEN ACCESS}




\title{
energy fuels
}

Subscriber access provided by The University of Manchester Library

\section{Article}

\section{Efficiency of carbon dioxide storage and enhanced methane recovery in a high rank coal}

\author{
Mojgan Hadi Mosleh, Majid Sedighi, Philip J. Vardon, and Matthew Turner
}

Energy Fuels, Just Accepted Manuscript • DOI: 10.1021/acs.energyfuels.7b02402 • Publication Date (Web): 17 Nov 2017

Downloaded from http://pubs.acs.org on November 19, 2017

\section{Just Accepted}

"Just Accepted" manuscripts have been peer-reviewed and accepted for publication. They are posted online prior to technical editing, formatting for publication and author proofing. The American Chemical Society provides "Just Accepted" as a free service to the research community to expedite the dissemination of scientific material as soon as possible after acceptance. "Just Accepted" manuscripts appear in full in PDF format accompanied by an HTML abstract. "Just Accepted" manuscripts have been fully peer reviewed, but should not be considered the official version of record. They are accessible to all readers and citable by the Digital Object Identifier (DOI®). "Just Accepted" is an optional service offered to authors. Therefore, the "Just Accepted" Web site may not include all articles that will be published in the journal. After a manuscript is technically edited and formatted, it will be removed from the "Just Accepted" Web site and published as an ASAP article. Note that technical editing may introduce minor changes to the manuscript text and/or graphics which could affect content, and all legal disclaimers and ethical guidelines that apply to the journal pertain. ACS cannot be held responsible for errors or consequences arising from the use of information contained in these "Just Accepted" manuscripts. 


\section{Efficiency of carbon dioxide storage and enhanced methane} recovery in a high rank coal

3

\author{
* Corresponding author (email: mojgan.hadimosleh@manchester.ac.uk) \\ Mojgan Hadi Mosleh ${ }^{1,2 *}$, Majid Sedighi ${ }^{1,2}$, Philip J. Vardon ${ }^{1,3}$, and Matthew Turner ${ }^{1,4}$ \\ ${ }^{1}$ Geoenvironmental Research Centre, School of Engineering, Cardiff University, The Queen's \\ Buildings, Newport Road, Cardiff, CF24 3AA, UK \\ ${ }^{2}$ School of Mechanical, Aerospace and Civil Engineering, The University of Manchester, \\ Manchester, M13 9PL, UK \\ ${ }^{3}$ Section of Geo-Engineering, Faculty of Civil Engineering and Geosciences, Delft University of \\ Technology, 2600 GA, Delft, The Netherlands \\ ${ }^{4}$ IHS Global Limited, Enterprise House, Cirencester Road, Tetbury, GL8 8RX, UK
}

4 
17 High affinity and adsorption capacity of coal to carbon dioxide provides alternative approach for 18 the enhanced recovery of methane from unminable coalfields $\left(\mathrm{CO}_{2}\right.$-ECBM) by which a potential 19 solution for long-term $\mathrm{CO}_{2}$ sequestration in deep geological formations can also be achieved. 20 However, due to chemo-mechanical effects induced by the interactions between $\mathrm{CO}_{2}$ and coal, the 21 effective methane production and carbon dioxide storage can be degraded which has caused 22 uncertainties about the techno-economic feasibility of the $\mathrm{CO}_{2}$-ECBM process. This study presents 23 an experimental investigation that aims to address key knowledge gaps related to the efficiency of $24 \mathrm{CO}_{2}$ storage and $\mathrm{CH}_{4}$ recovery in high rank coals for which comprehensive experimental data set 25 and analysis are largely missing. Competitive displacements of $\mathrm{CH}_{4}$ with $\mathrm{N}_{2}$ or $\mathrm{CO}_{2}$ in an 26 anthracite coal sample from South Wales coalfield have been studies, based on a series of core 27 flooding experiments.

28 The results show that the $\mathrm{N}_{2}$ breakthrough time (the time at which $1 \%$ of the total gas injected was 29 recovered) was almost spontaneous whereas a considerably delayed breakthrough time was 30 observed for the case of $\mathrm{CO}_{2}$-ECBM experiment. In addition it was observed that for the $\mathrm{CO}_{2}-$ 31 ECBM experiment, the ratios of $\mathrm{CH}_{4}$ recovery with respect to the total amount of gas injected and 32 gas stored were higher by factors of 10 and 2.4 , respectively. The results also show that $90 \%$ of the 33 total $\mathrm{N}_{2}$ injected was produced in the outflow gas, whereas for the case of the $\mathrm{CO}_{2}$ experiment, only $3463 \%$ of the total injected $\mathrm{CO}_{2}$ was produced. Presence of high amount of $\mathrm{N}_{2}$ in the outflow may 35 lead to additional challenges in order to separate $\mathrm{N}_{2}$ from $\mathrm{CH}_{4}$ and thus affects the efficiency of the $36 \mathrm{~N}_{2}$-ECBM method. Under the conditions of the experiments, the total $\mathrm{CH}_{4}$ displacement ratio and 37 breakthrough for the case $\mathrm{CO}_{2}-\mathrm{ECBM}$ were found to be more favorable compared to those obtained 38 from $\mathrm{N}_{2}$-ECBM. This study provides new insights into the efficiency of $\mathrm{CO}_{2}$-ECBM process and 39 offers a comprehensive experimental data set that can be used for testing the accuracy of predictive 40 models. 
1

2

3

4

5

6

7

8

9

10

11

12

13

14

15

16

17

18

19

20

21

22

23

24

25

26

27

28

29

30

31

32

33

34

35

36

37

38

39

40

41

42

43

44

45

46

47

48

49

50

51

52

53

54

55

56

57

58

59

60
41 Keywords: $\mathrm{CO}_{2}$ sequestration, enhanced coalbed methane recovery (ECBM), anthracite coal, core

42 flooding, gas permeability, gas sorption, South Wales coalfield. 


\section{1. Introduction}

45 The process of coalbed methane (CBM) production from unminable coal fields usually involves the 46 pressure depletion in the coal reservoir by pumping out the naturally existing formation water. 47 However, the pressure depletion only allows a limited amount of in-place-gas $\left(\mathrm{CH}_{4}\right)$ to be produced 48 because the methane is adsorbed on the coal even at low pressures (White et al., 2005). As a result, 49 approximately 30 to $70 \%$ of the in-place-gas in coal cannot be recovered using the conventional 50 pressure depletion method (Puri and Yee, 1990). Enhanced coalbed methane (ECBM) recovery is a 51 process by which $\mathrm{N}_{2}$ or $\mathrm{CO}_{2}$ (or a mixture of both) is injected into the coal seam to enhance the 52 recovery of coalbed methane (White et al., 2005). In $\mathrm{N}_{2}-\mathrm{ECBM}, \mathrm{N}_{2}$ first displaces the free $\mathrm{CH}_{4}$ 53 from the seam and reduces the partial pressure of methane in the reservoir that enables further 54 methane in the adsorbed phase (in coal matrix) to be released (Shi and Durucan, 2005). However, 55 rapid breakthrough of $\mathrm{N}_{2}$ during the production of methane has been reported to be the major issue 56 in the field projects (Perera and Ranjith, 2015). Alternatively, $\mathrm{CO}_{2}$ has been suggested to enhance 57 the coalbed methane recovery $\left(\mathrm{CO}_{2}\right.$-ECBM) due to the higher affinity of coal to adsorb carbon 58 dioxide compared to methane that may result in larger amount of coalbed methane production. In 59 addition, the potential long term sequestration of $\mathrm{CO}_{2}$ in deep unminable coal seams during the 60 process of $\mathrm{CO}_{2}$-ECBM is an advantage over the $\mathrm{N}_{2}$-ECBM process (Shi and Durucan, 2005).

61 Permeability evolution in coal as the result of changes in effective stress and sorption-induced 62 swelling and shrinkage during ECBM process has been extensively studies by researchers, through 63 laboratory investigation and numerical modeling, e.g. Feng et al. (2017), Hadi Mosleh et al, (2017), 64 Liu and Harpalani (2013), Ma et al. (2011).

65 Experimental studies show that coal can exhibit shrinkage or swelling during interaction with 66 different gas species, e.g. Mazumder et al. (2006), Mazzotti et al. (2009), Hadi Mosleh (2014).

67 Therefore, the uptake or release of $\mathrm{CO}_{2}$ and $\mathrm{CH}_{4}$ is a combination of adsorption/desorption 
processes and coal swelling/shrinkage that can affect the permeability of the coal, resulting in the overall rate and efficiency of methane recovery and carbon dioxide storage.

Observations from limited pilot tests of carbon sequestration in coal seams that have been reported

72 as the result of reduction in coal permeability induced by swelling (Reeves and Oudinot, 2005;

73 Yamaguchi et al. 2006; van Bergen et al. 2006). However, the outcomes of the field tests reported 74 have largely remained inconclusive (Pan and Connell, 2012). A limited number of lab-scale 75 experimental studies have also been reported on processes related to enhanced coalbed methane or $\mathrm{CO}_{2}$ (or a mixture if gas) is injected into the sample. The composition of the outflow gas is monitored during the test to evaluate the breakthrough time of the injected gas, displacement of

81 gases and the rate of gas storage/recovery. Wang et al. (2010) carried out a series of gas storage and recovery experiments on highly volatile bituminous coal and showed that for the example considered, the amount of the adsorbed $\mathrm{CO}_{2}$ was two orders of magnitude larger as compared to the amount of desorbed $\mathrm{CH}_{4}$. Yu et al. (2008) has reported gas storage and recovery experiments on coal samples originated from Qinshui basin in China. The results show that initially the $\mathrm{CO}_{2}$ fraction in the outflow gas was very small compared to the $\mathrm{CH}_{4}$ and the initial $\mathrm{CH}_{4}$ displacement with $\mathrm{CO}_{2}$ was not associated with the $\mathrm{CO}_{2}$ release. They have also shown that with an increase of

88 the volume of replaced $\mathrm{CH}_{4}$, the discharge capacity of $\mathrm{CO}_{2}$ has slowly increased.

89 Compared to the extensive experimental investigations carried out on adsorption/desorption 90 characteristics and permeability properties of coal to gas species, the laboratory scale experimental 91 studies on the process of $\mathrm{N}_{2}$-ECBM and $\mathrm{CO}_{2}$-ECBM are very limited and comparative assessment 92 of the efficiency of enhanced methane recovery by $\mathrm{N}_{2}$ and $\mathrm{CO}_{2}$ is still lacking. In the last decade 93 several conceptual models have been developed to account for the flow of gas in coal and fractured 
94 rock (e.g. Shi and Durucan, 2003; Salimzadeh and Khalili, 2015; Hosking, 2014). These models are

95 usually based on mechanistic approaches that require appropriate constitutive relationships (e.g.

96 gas permeability model) and experimental data for testing. Data sets generated from laboratory

97 scale experiments on $\mathrm{N}_{2}-\mathrm{ECBM}$ and $\mathrm{CO}_{2}$-ECBM are critical bench marks for testing such

98 numerical models that can be used for simulation and design of the process at field scale.

99 However, the experimental studies that contain adequate material properties and provide

100 constitutive relationships for numerical modeling are scarce, especially for high rank coals, i.e.

101 anthracite. In this work, we aim to address i) gaps in knowledge related to the response of a high

102 rank coal to gas injection, displacement and storage during ECBM process, and ii) the lack of

103 adequate and comprehensive experimental dataset required for testing the predictive models. In this

104 paper, an experimental investigation on the process of $\mathrm{N}_{2}$-ECBM and $\mathrm{CO}_{2}$-ECBM in a high rank

105 coal from South Wales coalfield is presented and comparative assessment of the efficiency based

106 on gas recovery and storage for both $\mathrm{N}_{2}-\mathrm{ECBM}$ and $\mathrm{CO}_{2}-\mathrm{ECBM}$ is discussed. Core flooding

107 experiments have been conducted in which $\mathrm{N}_{2}$ and $\mathrm{CO}_{2}$ were injected into the $\mathrm{CH}_{4}$-saturated coal

108 sample to evaluate the competitive displacement of $\mathrm{CH}_{4}$ with $\mathrm{N}_{2}$ and $\mathrm{CO}_{2}$ under simulated

109 underground conditions. The displacement process, gas breakthrough, and recovery ratios are also

110 discussed.

\section{2. Material and methods}

112 The anthracite coal sample used in this work was obtained from the Six Feet coal seam, at the

113 Unity coal mine located in South Wales, UK (Hadi Mosleh et al., 2017). Blocks of coal with

114 dimensions of approximately $0.5 \times 0.5 \times 0.5 \mathrm{~m}$ were collected from the depth of approximately $550 \mathrm{~m}$.

115 Prior to core flooding experiments, a series of coal characterisation tests including the Proximate 116 and Ultimate Analyses (BS 1016-104 and BS 1016-106) were conducted on crushed samples in 117 order to determine key properties of moisture content, ash content, and volatile matter as well as

118 elemental composition such as sulphur and carbon contents. Table 1 presents a summary of the 119 physical and chemical properties of the coal used. 


\subsection{Preparation of core samples}

121 The core sample used was drilled from a large block of coal using a diamond core drill bit with

$12270 \mathrm{~mm}$ internal diameter. The core sample was then cut into the required length using a diamond

123 saw. Special care was taken during the coring and cutting processes to minimise breakage or

124 damage to the coal structure. Any small breakage especially around the edges could potentially

125 damage or puncture the rubber membrane during triaxial core flooding tests and under the high

126 confining pressures and therefore had to be removed. In order to prevent breakage of the coal

127 samples under high stress conditions, the ends of the specimens were ground and made parallel to

128 each other using a fine sand paper. This allowed a uniform distribution of the axial stresses to both

129 ends of the sample. In order to remove any residual moisture, the core sample was then air-dried

130 for $24 \mathrm{hr}$ before it was placed in the triaxial cell for the tests.

\section{$131 \quad$ 2.2. Triaxial core flooding setup}

132 Triaxial core flooding setup was designed and developed by Hadi Mosleh (2014). The experimental

133 setup comprises i) a high pressure triaxial core flooding system, ii) a pressure control system, iii) a

134 temperature control system, and iv) an ancillary system including gas supply and analysing units. A

135 schematic diagram of the developed laboratory facility is presented in Figure 1 (Hadi Mosleh et al., 136 2017).

137 The core sample sits within a $1.5 \mathrm{~mm}$ thick silicone rubber sleeve and the gas passes through a 138 porous plate at the bottom of the sample, then it leaves the cell through a similar arrangement at the 139 top after having passed through the test core. A Mass Flow Meter capable of measuring high flow 140 rates up to $17 \times 10^{-6} \mathrm{~m}^{3} / \mathrm{s}(1 \mathrm{~L} / \mathrm{min})$ is connected to the outlet which is capable of working under both 141 subcritical and supercritical conditions, with pressures up to 20MPa.

142 The pressure control system includes a pressure/volume controller to control the confining pressure 143 and a high pressure regulator with a needle valve to control the gas pore pressure. Two 32MPa in144 line pore pressure transducers were selected to measure the inlet and the outlet gas pressures. The 145 confining system consists of a $32 \mathrm{MPa}$ pressure/volume controller with a $2 \times 10^{-4} \mathrm{~m}^{3}(200 \mathrm{~mL})$ oil 
146 reservoir. Volume changes can be measured and displayed to $1 \times 10^{-9} \mathrm{~m}^{3}(0.001 \mathrm{~mL})$. The confining

147 pressure is provided by silicone oil 350 (Polydimethylsiloxane) and a hydraulic pump. The 148 composition of the outflow gases was determined using an Emerson X-Stream general purpose gas 149 analyser (standard $19 " / 3 \mathrm{HU}$ version) with the optimum gas flow rate of $1.7 \times 1^{-5} \mathrm{~m}^{3} / \mathrm{s}(1 \mathrm{~L} / \mathrm{min})$ and $150 \pm 0.01 \%$ accuracy of Full Range Output (FRO). More details of the design and development of the 151 laboratory setup can be found in Hadi Mosleh et al. (2017).

\section{$152 \quad$ 2.3. Experimental procedure}

153 The core sample of $70 \mathrm{~mm}$ diameter and $100 \mathrm{~mm}$ length was carefully wrapped with a thick PTFE 154 tape before being placed in the silicone rubber sleeve. The displacement transducers, two axial and 155 one radial, and three thermocouples were then attached to the sample. The top cap was placed on 156 the base pedestal and the cell was filled with the silicone oil. The temperature of the system was 157 adjusted to $25^{\circ} \mathrm{C}$ (the corresponding temperature of the depth at which the sample was taken), using 158 four heating elements attached to the cell's body and a programmable controller. The temperature 159 was kept constant throughout the test. A confining pressure of $1 \mathrm{MPa}$ was applied and the sample 160 was subjected to vacuum for 24 hours to remove the residual moisture and gases from the pore 161 space. Prior to each core flooding test, the core sample was saturated with the chosen gas.

162 The steady-state method has been used to estimate permeability of the coal sample (Carles et al., 163 2007). For the initial permeability measurements, the confining pressure was maintained at the 164 desired pressure and increased stepwise. Once the steady-state flow rate was achieved at each step, 165 the differential gas pressures and gas flow rates were recorded. The permeability of the coal sample 166 was calculated using Darcy's law (Carman, 1956), given as:

$$
k_{g}=\frac{2 Q_{0} \mu_{g} L P_{0}}{A\left(P_{u p}^{2}-P_{d o w n}^{2}\right)}
$$

167 where, $k_{g}$ is the gas permeability coefficient $\left(\mathrm{m}^{2}\right), Q_{0}$ is the volumetric rate of flow $\left(\mathrm{m}^{3} / \mathrm{s}\right), \mu_{g}$ is the 168 viscosity of the gas (Pa.s), $L$ is the sample length (m) and $P_{0}$ refers to the reference pressure (Pa) 
169 which in this study was atmospheric pressure, i.e. $1 \times 10^{-5} \mathrm{~Pa}$. $A$ is the cross-sectional area of the 170 sample $\left(\mathrm{m}^{2}\right), P_{u p}$ is the upstream gas pressure $(\mathrm{Pa})$, and $P_{\text {down }}$ is the downstream gas pressure (Pa).

171 The viscosity of gases $\left(\mu_{g}\right)$ was calculated as function of temperature, using the Sutherland formula 172 (Smits and Dussauge, 2006).

173 The experimental tests carried out based on the steps summarised in Figure 2:

\section{Stage 1: Flow characterisation of the coal sample}

175 Since helium is a non-adsorptive/non-reactive gas it was used to characterise the coal sample for its 176 intrinsic permeability and to investigate the mechanical effect of stresses on permeability of coal 177 during gas injection and depletion processes. The intrinsic permeability to helium has been used as 178 a key material property to compare gas flow behaviour of the coal sample used in this study with 179 those from previous studies, i.e. Hadi Mosleh (2014), and also to evaluate the changes in 180 permeability of the same coal sample with respect to gas species. The permeability of the coal 181 sample to helium was estimated for a range of gas injection pressures (up to 5.5MPa) and at several 182 confining pressures (up to 6MPa). In order to evaluate the effects of confining pressure on the gas 183 flow properties of the coal sample, the confining pressure was first increased stepwise up to $6 \mathrm{MPa}$ 184 while gas injection pressure was kept constant at 3.5MPa. To assess the effect of pore pressure 185 changes on gas flow and permeability of the coal sample, gas pressure was increased gradually to $1865.5 \mathrm{MPa}$ while the confining pressure was kept constant (6MPa). The coal sample was then 187 subjected to vacuum for 24 hours and saturated with $\mathrm{CH}_{4}$ at $5 \mathrm{MPa}$ injection pressure and $6 \mathrm{MPa}$ 188 confining pressure. The permeability of the coal to $\mathrm{CH}_{4}$ was measured by performing a $\mathrm{CH}_{4}$ 189 flooding experiment under a range of gas injection pressures from 3.5 to 5.5MPa.

\section{Stage 2: $\mathbf{N}_{2}$ - and $\mathbf{C O}_{2}$-ECBM experiments}

191 The coal sample was re-saturated with $\mathrm{CH}_{4}$ at $5 \mathrm{MPa}$ injection pressure and 6MPa confining 192 pressure. $\mathrm{N}_{2}$ gas was then injected into the $\mathrm{CH}_{4}$-saturated at $5 \mathrm{MPa}$ injection pressure while the 193 downstream valve was at atmospheric pressure, i.e. 0.1MPa. The composition of the outflow gas 
194 was analysed during the experiment using the gas analyser. After the $\mathrm{N}_{2}$-ECBM experiment, the

195 residual gas was removed from the sample by applying vacuum. The sample was purged with $\mathrm{CH}_{4}$

196 While the composition of outflow gas was monitored using the gas analyser until no residual $\mathrm{N}_{2}$

197 was present in the outflow. The sample was then re-saturated with $\mathrm{CH}_{4}$, and $\mathrm{CO}_{2}$ subsequently was

198 injected at $5 \mathrm{MPa}$. The confining pressure was kept constant throughout at $6 \mathrm{MPa}$. The composition

199 of the outflow gas was monitored continuously and the test was continued until $\mathrm{CH}_{4}$ was mostly

200 displaced with $\mathrm{CO}_{2}$. Figure 3 presents a schematic diagram of the experimental conditions applied

201 for the $\mathrm{N}_{2}$ - and $\mathrm{CO}_{2}$-ECBM experiments.

\section{3. Results and discussions}

203

\subsection{Helium flooding experiment}

204 For low permeability coals, the flow behaviour is highly dependent on the effective stress (Huy et

205 al., 2010). For incompressible fluid such as water, the effective stress is defined as the difference 206 between the confining pressure and linear mean gas pressure across the sample (Harpalani and 207 Chen, 1997):

$$
\sigma_{e f f}=P_{c}-\frac{P_{u p}+P_{\text {down }}}{2}
$$

208 where, $\sigma_{\text {eff }}$ is the effective stress and $P_{c}$ is the confining pressure.

209 Since gas is compressible, its bulk density varies greatly which in turn has a significant effect on

210 gas transport within the porous medium. Therefore unlike incompressible fluids, variation of gas

211 pore pressure across sample length is not expected to be linear. In this study, the analytical solution

212 presented by $\mathrm{Wu}$ et al. (1998) has been used to estimate the changes in gas pore pressure across the

213 sample at steady-state flow conditions:

$$
P(x)=-b+\sqrt{b^{2}+P_{L}^{2}+2 b P_{L}+2 q_{m} \mu(L-x) / k_{\infty} \beta}
$$

214 where, $P(x)$ is the gas pressure $(\mathrm{Pa})$ at linear distance $\mathrm{x}(\mathrm{m}), b$ is the Klinkenberg coefficient, $P_{L}$ is 215 the gas pressure at outlet boundaries of linear flow systems $(\mathrm{Pa}), q_{m}$ is the gas mass injection or 
216 pumping flux $\left(\mathrm{kg} / \mathrm{s} \cdot \mathrm{m}^{2}\right), L$ is the length of linear flow systems or thickness of unsaturated zone (m),

$217 k_{\infty}$ is the absolute permeability $\left(\mathrm{m}^{2}\right)$, and $\beta$ is the compressibility factor; $\mu$ viscosity (Pa.s).

218 The length of the sample was divided into 7 sections of $0.02 \mathrm{~m}$ long, and for each section the 219 average pore pressure was estimated using Eq. (3). In general, the average pore pressure within the coal sample obtained from Eq. (3) was found to be approximately $26-28 \%$ higher than average pore pressure obtained from linear approximation method. The mean gas pore pressure obtained from Eq. (3) was then used to estimate the effective stress, using Eq. (2).

The variations of permeability of the coal sample to helium with effective stress are presented in Figure 4a. Based on the results, the permeability of the coal sample ranges between 0.15 and $0.45 \times 10^{-15} \mathrm{~m}^{2}$ over the range of applied pressures and confining stresses applied. Variations in confining pressure and gas pore pressure showed slightly different effects on permeability evolution of the coal sample, however the overall trends of permeability behaviour as a result of changes in confining pressure and gas pore pressure were similar, i.e. the coal permeability to helium was reduced with increase in effective stress. These results are consistent with the results of another series of core flooding experiments performed by Hadi Mosleh (2014) on a similar coal sample (sister sample) obtained from same block of coal (Figure 4b). Coal permeability variations with effective stress can be attributed to the expansion or closure of the internal fractures and microfractures (Vishal et al., 2013). Non-linear evolution of coal permeability to gases with effective stress has been reported by other researchers (e.g. Feng et al., 2016; Mitra et al., 2012).

\section{2. $\mathrm{CH}_{4}$ flooding experiment}

The $\mathrm{CH}_{4}$ core flooding experiment was performed to evaluate the initial permeability of the coal sample to $\mathrm{CH}_{4}$ before introducing $\mathrm{CO}_{2}$ during the gas storage and recovery experiments and its consequent swelling effect on gas flow properties of coal. The results of the coal permeability to $\mathrm{CH}_{4}$ versus effective stress are presented in Figure 5. The coal permeability to $\mathrm{CH}_{4}$ was found to vary between $0.03 \times 10^{-15} \mathrm{~m}^{2}$ and $0.14 \times 10^{-15} \mathrm{~m}^{2}$ under the applied stresses. In general, the permeability of the coal sample to $\mathrm{CH}_{4}$ was found to be one order of magnitude lower than that to 
242 helium which can be mainly related to their differences in molecular size. The effect of gas 243 sorption-induced permeability evolution of coal should also be taken into account when 244 interpreting such results. The range of permeability evolution of coal reported in the literature as 245 the result of $\mathrm{CH}_{4}$ interaction with coal matrix varies greatly. For instance, Harpalani and Mitra 246 (2010) have reported a $\mathrm{CH}_{4}$ permeability reduction of approximately $25 \%$ compared to the original 247 value, whereas in a study conducted by by Milewska-Duda et al. (2000), the effect of $\mathrm{CH}_{4}$ on coal 248 matrix swelling and permeability reduction was found to be negligible, compared to highly reactive 249 gases such as $\mathrm{CO}_{2}$.

250 Once the evaluation of the initial properties of the coal sample was completed, the coal sample was 251 re-saturated with $\mathrm{CH}_{4}$ at injection pressure of $5 \mathrm{MPa}$ and confining pressure of $6 \mathrm{MPa}$.

\section{3. $\mathrm{N}_{2}-\mathrm{ECBM}$ recovery}

253 The results of the gas displacement process during the $\mathrm{N}_{2}$-ECBM experiment are presented in 254 Figure 6. The results present the variation of the gas composition in the outflow with time. It can be 255 observed that an early breakthrough of the injected $\mathrm{N}_{2}$ has occurred shortly after the injection 256 process was started. The definition of the breakthrough time of the injected gas varies in the 257 literature. A common definition for the breakthrough in work related to gas storage and recovery 258 processes has been considered here which is described as the time at which $1 \%$ of the total gas 259 injected is recovered (van Hemert et al., 2012; Mazumder and Wolf, 2008; Ross, 2007). In this 260 case, the breakthrough time was less than 100s.

261 The breakthrough time reported in the literature might vary greatly ranging from several minutes to 262 several days depending on the coal type, sample size, permeability, gas injection pressure, injection 263 rate and effective stresses, e.g. Connell et al. (2011), Shi et al. (2008), Yu et al. (2008). The early 264 breakthrough observed in the $\mathrm{N}_{2}$-ECBM experiment and relatively fast displacements of $\mathrm{CH} 4$ are 265 primarily related to the displacement of the free gas existing within the coal cleats/microfractures 266 rather than the free gas in the coal matrix. This is related to the experimental conditions in which a 267 relatively high injection pressure has been applied under low effective stress on the sample. 
268 The results presented in Figure 6 show that within the first half an hour of the experiment, more 269 than $95 \%$ of the production gas consisted of $\mathrm{N}_{2}$. Rapid changes in $\mathrm{N}_{2}$ and $\mathrm{CH}_{4}$ fractions at this stage 270 of the experiment can be attributed to the displacement of the free or weakly adsorbed $\mathrm{CH}_{4}$ 271 molecules with $\mathrm{N}_{2}$. Therefore, the dominant gas exchange process at this stage was the differences 272 in the partial pressures of $\mathrm{N}_{2}$ and $\mathrm{CH}_{4}$ within the coal cleats and microfractures. As the experiment 273 continued, the rate of changes in the fraction of $\mathrm{CH}_{4}$ in the production gas became very slow and 274 remained steady and continuous. This can be related to the slow diffusion of $\mathrm{N}_{2}$ and $\mathrm{CH}_{4}$ in the coal 275 matrix (Cui et al., 2004), which is the dominant gas exchange process at this stage of the

\section{4. $\mathrm{CO}_{2}-\mathrm{ECBM}$ recovery}

The experimental results of the gas displacement process during the $\mathrm{CO}_{2}$-ECBM experiment are presented in Figure 7 which shows the variations of gas composition in the production gas with time as a result of $\mathrm{CH}_{4}$ displacement with $\mathrm{CO}_{2}$. The small spikes on the graph are related to the minor fluctuations in the injection pressure generated as a result of simultaneous operation of the gas booster.

From the results presented, it is apparent that the breakthrough time of $\mathrm{CO}_{2}$ is two times slower than the $\mathrm{N}_{2}$-ECBM experiment that can be attributed to a combination of gas diffusion process in the coal and the effects of coal matrix swelling induced by the $\mathrm{CO}_{2}$ adsorption. Although, the volumetric deformation has not been directly measured in the experiments presented here, reduction in the mass flow rate of outflow gas during the $\mathrm{CO}_{2}$-ECBM experiment demonstrate the significance of the effect of coal swelling on the flow process. The mass flow rates recorded at downstream of the sample reduced from $14 \mathrm{~g} / \mathrm{h}$ to $1 \mathrm{~g} / \mathrm{h}$ during the course of $\mathrm{CO}_{2}$-ECBM experiment (more than 5 hours), whereas for the case of $\mathrm{N}_{2}$-ECBM experiment, the recorded mass-flow rates remained relatively steady throughout the experiment, i.e. $28-34 \mathrm{~g} / \mathrm{h}$. 
293 With its relatively smaller kinetic diameter, $\mathrm{CO}_{2}$ molecules can penetrate into the micro-pores of 294 coal which are inaccessible or less accessible to $\mathrm{CH}_{4}$ and $\mathrm{N}_{2}$ molecules that have larger kinetic 295 diameters. This can result in one or two orders of magnitude higher diffusivity of $\mathrm{CO}_{2}$ in the coal 296 matrix compared with $\mathrm{N}_{2}$ and $\mathrm{CH}_{4}$ (Cui et al., 2004). Hence, the higher diffusion of $\mathrm{CO}_{2}$ than that 297 for $\mathrm{CH}_{4}$ and $\mathrm{N}_{2}$ may limit its breakthrough in the production gas through faster diffusion into the 298 coal matrix. Moreover, the effect of the coal swelling induced by $\mathrm{CO}_{2}$ adsorption can also result in 299 slower rate of gas flow in the cleat and consequently increases the time of the breakthrough.

300 The results of the gas storage and recovery experiments show that, the overall rate of $\mathrm{CO}_{2}$ 301 displacement with $\mathrm{CH}_{4}$ is much slower compared to case for $\mathrm{N}_{2}$. For the $\mathrm{N}_{2}$ experiment, more than $30295 \%$ of $\mathrm{CH}_{4}$ has been displaced within less than 30 minutes, whereas for the case of $\mathrm{CO}_{2}$ 303 experiment, the fraction of displaced $\mathrm{CH}_{4}$ has almost reached $90 \%$ after 3 hours of continuous $\mathrm{CO}_{2}$

304 injection. As stated earlier, higher diffusion rate of $\mathrm{CO}_{2}$ and the effect of sorption-induced swelling 305 on coal matrix during the $\mathrm{CO}_{2}$-ECBM process can together govern the slower gas displacement 306 rates observed. Whereas, in the $\mathrm{N}_{2}$-ECBM process, the slower rate of $\mathrm{N}_{2}$ diffusion into the coal 307 matrix leads to relatively higher partial pressure of $\mathrm{N}_{2}$ gas within the coal cleats and therefore faster 308 gas displacement rate and $\mathrm{N}_{2}$ breakthrough is observed.

\section{$309 \quad$ 3.5. Gas storage and recovery in coal}

310 Based on the experimental data of gas flow rates at upstream and downstream obtained from two 311 mass flow meters, and the composition of the outflow gas obtained from gas analyser, the upstream 312 and downstream mass flow rates were estimated and converted to mole per second $(\mathrm{mol} / \mathrm{s})$. The 313 cumulative amounts of gas injected, recovered and stored in the coal sample were then calculated

314 for each experiment. It should be mentioned that the gas storage here implies the total amount of 315 gas adsorbed to the coal matrix as well as the free gas stored in cleats/microfractures and matrix 316 pore volume. Figures 8 and 9 present the cumulative amounts of gas injected, recovered and stored 317 in the coal sample during $\mathrm{N}_{2}$ - and $\mathrm{CO}_{2}$-ECBM experiments, respectively. 
318 The results presented in Figures 8 and 9 show that for the same duration of the experiment and 319 under similar experimental conditions, the total amount of injected $\mathrm{N}_{2}$ was 11 times higher than 320 that for $\mathrm{CO}_{2}$ injection. In addition, the results show that $90 \%$ of the total injected $\mathrm{N}_{2}$ was in the 321 production gas, whereas in the case of the $\mathrm{CO}_{2}$ experiment, only $63 \%$ of the total injected $\mathrm{CO}_{2}$ was 322 in the production gas. Therefore $36 \%$ of the injected $\mathrm{CO}_{2}$ has been retained within the coal sample.

323 In another study conducted by Hadi Mosleh (2014), the maximum adsorption capacity of the same 324 coal to $\mathrm{CO}_{2}$ was estimated $1.21 \mathrm{~mol} / \mathrm{kg}$. By assuming the total amount of stored $\mathrm{CO}_{2}$ during $\mathrm{CO}_{2}-$ 325 ECBM experiment as adsorbed gas, it can be postulated that only $20 \%$ of the adsorption capacity of 326 coal sample to $\mathrm{CO}_{2}$ was utilised. This can be related to several factors:

327 - Effect of gas diffusion rate: the gas adsorption isotherms were measured on powdered coal 328 samples and over 24 to 48 hours, when the equilibrium state was observed (Hadi Mosleh, 2014), 329 whereas the experiments of this study have been conducted on intact $70 \mathrm{~mm}$ core samples, and 330 over shorter durations ( $4 \mathrm{hr})$. Therefore, much longer time was needed for the gas to diffuse 331 into the coal matrix and to achieve equilibrium state.

- Effect of coal swelling: coal swells when it comes into contact with $\mathrm{CO}_{2}$, this resulted in

333 reduction of coal permeability under confined conditions and therefore a reduction in the 334 accessibility of the coal matrix to more $\mathrm{CO}_{2}$ gas.

- Effect of effective stress on coal permeability: in gas adsorption measurements by Hadi Mosleh 336 (2014), powdered coal was placed in a high pressure cell without confining pressure applied to 337 coal sample. Whereas in this study, the results of helium and $\mathrm{CH}_{4}$ flooding experiments have 338 shown that permeability of the coal decreases as effective stress increases. This is related to 339 compression of fractures and microfractures and therefore reduction in accessibility of coal $340 \quad$ matrix to gas.

\section{$341 \quad$ 3.6. Efficiency of $\mathbf{C H}_{4}$ recovery}


342 Figure 10 shows the cumulative amounts of $\mathrm{CH}_{4}$ recovered during the $\mathrm{N}_{2}-\mathrm{ECBM}$ and $\mathrm{CO}_{2}-\mathrm{ECBM}$ 343 experiments. From the results, it may be suggested that the total amounts of $\mathrm{CH}_{4}$ recovered in $\mathrm{N}_{2-}$

344 and $\mathrm{CO}_{2}$-ECBM experiments are almost equal $(0.187 \mathrm{~mol}$ and $183 \mathrm{~mol}$, respectively) and therefore 345 both methods can be equally effective in terms of $\mathrm{CH}_{4}$ recovery. However the rate of $\mathrm{CH}_{4}$ recovery, 346 which is an important factor affecting the success of ECBM application, should be taken into 347 account when interpreting such results. The results presented in Figure 10 show that the rate of $\mathrm{CH}_{4}$ 348 recovery for the case of $\mathrm{N}_{2}$ injection was significantly higher at the early stages of the experiment 349 and reduced considerably for much of the experiment's duration; whereas for the case of $\mathrm{CO}_{2}$ 350 injection, the rate of $\mathrm{CH}_{4}$ was found to be more or less steady throughout the experiment. Similar 351 observations have been reported by $\mathrm{Yu}$ et al. (2008) based on the core flooding experiments 352 conducted on coal samples from Qinshui basin in North China.

353

354 In addition, the efficiency of $\mathrm{CH}_{4}$ recovery from coal can be related to other factors including: i) 355 the amount of gas required for the injection, ii) the fraction of injected gas in the production gas 356 which needs to be separated from $\mathrm{CH}_{4}$, and iii) the amount of gas that can be stored in coal which 357 is particularly important for the case of $\mathrm{CO}_{2}$ sequestration process. Figures 11 and 12 present the 358 ratio of $\mathrm{CH}_{4}$ recovery with respect to the amount of gas injected and stored, respectively, during 359 both $\mathrm{N}_{2}$ and $\mathrm{CO}_{2}$ experiments.

360 The results of $\mathrm{CH}_{4}$ recovery versus injected gas (Figure 11) indicate that the $\mathrm{CO}_{2}$ injection lead to a 361 higher ratio of $\mathrm{CH}_{4}$ recovery throughout the experiment (up to 10 times higher than that obtained 362 by $\mathrm{N}_{2}$ injection). This is mainly related to the higher amounts of $\mathrm{N}_{2}$ injected under similar 363 experimental conditions, i.e. gas injection pressure and confining pressure. The amount of the $\mathrm{CH}_{4}$ 364 recovery for both experiments decreased sharply in the first hour of the experiments. The rate of $365 \mathrm{CH}_{4}$ recovery, however, remained almost steady for the $\mathrm{N}_{2}$ experiment after the first hour, whereas 366 for the $\mathrm{CO}_{2}$ experiment, it decreased gradually over time. This behaviour can be attributed to the 367 effect of coal matrix swelling on gas permeability and flow as described previously. 
368 The results of $\mathrm{CH}_{4}$ recovery versus stored gas (Figure 12) also show that storage of $\mathrm{CO}_{2}$ lead to

369 higher ratio of $\mathrm{CH}_{4}$ recovery (on average 2.4 times higher than that obtained by $\mathrm{N}_{2}$ injection). In

370 other words, for every mole of $\mathrm{CO}_{2}$ stored in the coal sample $1.2 \mathrm{~mol}$ of $\mathrm{CH}_{4}$ was recovered. Higher

371 ratios have also been reported in the literature, e.g. a ratio of 2 to 1 (Tsotsis et al., 2004) which can

372 be related to the differences in coal type (different sorption capacities and gas flow and mechanical

373 properties) and the experimental conditions.

\section{4. Conclusions}

375 The results of gas storage and recovery from a series of experiments conducted on the $\mathrm{CH}_{4}$ 376 saturated coal sample were presented on a high rank coal from South Wales coalfield. $\mathrm{N}_{2}$ and $\mathrm{CO}_{2}$ 377 were injected at the upstream of the sample and composition of outflow gas was monitored. The 378 results of both experiments were assessed and compared in terms of breakthrough time, gas 379 displacement rate, and efficiency of gas storage and recovery.

380 The results showed that the $\mathrm{N}_{2}$ breakthrough time was almost spontaneous whereas for the case of $381 \mathrm{CO}_{2}$, the breakthrough time was delayed by a factor of two. Similarly, the gas displacement rate 382 observed in both experiments varied greatly which was mostly related to differences between 383 diffusivity of $\mathrm{N}_{2}$ and $\mathrm{CO}_{2}$ as well as higher affinity of the coal to $\mathrm{CO}_{2}$. The latter effect also 384 resulted in storage of $36 \%$ of injected $\mathrm{CO}_{2}$ in coal. The results of $\mathrm{CH}_{4}$ recovery showed that with 385 respect to both injected and stored gas, the ratios of $\mathrm{CH}_{4}$ recovered during $\mathrm{CO}_{2}$ experiment were 386 higher than those for $\mathrm{N}_{2}$ experiment.

387 This study has shown that early $\mathrm{N}_{2}$ breakthrough and higher rate of $\mathrm{N}_{2}$ production may lead to 388 additional challenges in order to separate $\mathrm{N}_{2}$ from $\mathrm{CH}_{4}$ and thus affects the efficiency of the $\mathrm{N}_{2}$ 389 ECBM method. For the case of $\mathrm{CO}_{2}$, the total $\mathrm{CH}_{4}$ recovery, displacement ratio, breakthrough and $390 \mathrm{CO}_{2}$ storage are more favourable. In general, the displacement ratio, $\mathrm{CO}_{2}$ breakthrough time and $391 \mathrm{CO}_{2}$ storage are important parameters affecting the success of carbon sequestration application and 
392 the results of this study provide new insights into the efficiency of gas recovery and storage in

393 anthracite coal using carbon dioxide and under the experimental conditions applied.

\section{Acknowledgements}

395 The financial support received from the Welsh-European Funding Office as part of the

396 Geoenvironmental Research Centre's SEREN project is gratefully acknowledged. The authors

397 would like to thank Dr Snehasis Tripathy for his support. We also would like to thank GDS

398 Instruments for their contribution for construction and commissioning of laboratory equipment.

399 Technical support from the technicians and staff of the Engineering Workshop at Cardiff

400 University is also gratefully acknowledged.

\section{$401 \quad$ References}

402 Carles, P., Egermann, P., Lenormand, R. and Lombard, J. 2007. Low permeability measurements 403 using steady-state and transient methods. The International Symposium of the Society of Core 404 Analysts, Calgary, Canada. 10-14 September 2007.

405 Carman, P.C. 1956. Flow of gases through porous media. London: Butterworths.

406 Connell, L.D., Sander, R., Pan, Z., Camilleri, M. and Heryanto, D. 2011. History matching of 407 enhanced coal bed methane laboratory core flood tests. International Journal of Coal Geology, 408 87(2), 128-138.

409 Cui, X., Bustin, R.M. and Dipple, G. 2004. Selective transport of $\mathrm{CO}_{2}, \mathrm{CH}_{4}$ and $\mathrm{N}_{2}$ in coals: 410 insights from modeling of experimental gas adsorption data. Fuel, 83(3), pp. 293-303.

411 Durucan, S. and Edwards, J.S. 1986. The effects of stress and fracturing on permeability of coal. 412 Mining Science and Technology, 3(3), pp. 205-216.

413 Feng, R., Harpalani, S., and Pandey R. 2016. Laboratory measurement of stress-dependent coal 414 permeability using pulse-decay technique and flow modeling with gas depletion. Fuel, 177, pp. 7641586.

416 Feng, R., Harpalani, S., and Liu, J. 2017. Optimized pressure pulse-decay method for laboratory 417 estimation of gas permeability of sorptive reservoirs: Part 2 - Experimental study. Fuel, (191), pp. $418 \quad 565-573$.

419 Hadi Mosleh, M. 2014. An experimental investigation of flow and reaction processes during gas 420 storage and displacement in coal. PhD Thesis, Cardiff University.

421 Hadi Mosleh, M., Turner, M., Sedighi, M., and Vardon, P.J. 2017. High Pressure Gas Flow, 422 Storage and Displacement in Fractured Rock-Experimental Setup Development and Application, 423 Review of Scientific Instruments, 88(1), 015108:1-14. 
424 Harpalani, S. and Chen, G. 1997. Influence of gas production induced volumetric strain on permeability of coal. Geotechnical and Geological Engineering, 15(4), pp. 303-25.

426 Hosking, L. 2014. Reactive transport modelling of high pressure gas flow in coal. PhD Thesis, 427 Cardiff University.

428 Huy, P.Q., Sasaki, K., Sugai, Y. and Ichikawa, S. 2010. Carbon dioxide gas permeability of coal 429 core samples and estimation of fracture aperture width. International Journal of Coal Geology, 430 83(1), pp. 1-10.

431 Karacan, C.Ö. 2003. Heterogeneous sorption and swelling in a confined and stressed coal during $432 \mathrm{CO}_{2}$ injection. Energy and Fuels, 17(6), pp. 1595-1608.

433 Liu, S., and Harpalani, S. 2013. Permeability prediction of coalbed methane reservoirs during 434 primary depletion. International Journal of Coal Geology, 113, pp. 1-10.

435 Ma, Q., Harpalani, S., and Liu, S. 2011. A simplified permeability model for coalbed methane 436 reservoirs based on matchstick strain and constant volume theory. International Journal of Coal 437 Geology, 85(1), pp. 43-48.

438 Mazumder, S., Karnik, A. and Wolf, K.H. 2006. Swelling of coal in response to $\mathrm{CO}_{2}$ sequestration 439 for ECBM and its effect on fracture permeability. SPE Journal, 11(3), pp. 390-398.

440 Mazumder, S. and Wolf, K. 2008. Differential swelling and permability change of coal in response 441 to $\mathrm{CO}_{2}$ injection for ECBM. International Journal of Coal Geology, 74(2), pp. 123-138.

442 Milewska-Duda, J., Duda, J., Nodzenski, A. and Lakatos, J. 2000. Absorption and adsorption of 443 methane and carbon dioxide in hard coal and active carbon. Langmuir, 16(12), pp. 5458-5466.

444 Mitra, A., Harpalani, S., and Liu, S. 2012. Laboratory measurement and modeling of coal 445 permeability with continued methane production: Part 1 - Laboratory results. Fuel, 94, pp. 110446116.

447 Onur Balan, H. 2008. Modeling the effects of variable coal properties on methane production 448 during enhanced coalbed methane recovery. MSc Thesis, Middle East Technical University.

449 Pan, Z. and Connell, L.D. 2012. Modelling permeability for coal reservoirs: A review of analytical 450 models and testing data. International Journal of Coal Geology, 92(1), pp. 1-44.

451 Perera, M.S.A. and Ranjith, P.G. 2015. Enhanced Coal Bed Methane Recovery: Using Injection of 452 Nitrogen and Carbon Dioxide Mixture. Handbook of Clean Energy Systems, John Wiley \& Sons, 453 Ltd.

454 Puri, R., and Yee, D. 1990. Enhanced coalbed methane recovery. Society of Petroleum 455 Engineering, 65 ${ }^{\text {th }}$ Annual Techn. Conf., New Orleans (LA). Paper 20732, pp. 193-202.

456 Reeves, S., and Oudinot, A. 2005. The Allison unit $\mathrm{CO}_{2}-\mathrm{ECBM}$ pilot - a reservoir and economic 457 analysis. Proceedings of the 2005 International Coalbed Methane Symposium, Tuscaloosa, 458 Alabama. Paper 0522.

459 Ross, H.E. 2007. Carbon dioxide sequestration and enhanced coalbed methane recovery in 460 unmineable coalbeds of the Powder River Basin, Wyoming. PhD Thesis, Stanford University. 
461 Salimzadeh, S., and Khalili, N. 2015. Three-Dimensional Numerical Model for Double-Porosity 462 Media with Two Miscible Fluids Including Geomechanical Response. International Journal of 463 Geomechanics, 16(3).

464 Shi, J-Q., and Durucan, S. 2003. A bidisperse pore diffusion model for methane displacement 465 desorption in coal by $\mathrm{CO}_{2}$ injection. Fuel, 82(10), pp. 1219-1229.

466 Shi, J-Q., and Durucan, S. 2005. $\mathrm{CO}_{2}$ storage in deep unminable coal seams. Oil \& Gas Science 467 and Technology-Rev.IFP, 60(3), pp. 547-558.

468 Shi, J-Q., Mazumder, S., Wolf, K. and Durucan, S. 2008. Competitive methane desorption by 469 supercritical $\mathrm{CO}_{2}$ injection in coal. Transport in Porous Media, 75(1), pp. 35-54.

470 Smits, A.J. and Dussauge, J.P. 2006. Turbulent Shear Layers in Supersonic Flow. 2nd ed. New 471 York: American Institute of Physics.

472 Somerton, W.H., Soylemezoglu, I.M. and Dudley, R.C. 1975. Effect of stress on permeability of 473 coal. International Journal of Rock Mechanics and Mining Sciences \& Geomechanics, 12(5-6), pp. 474 129-45.

475 Tsotsis, T.T., Patel, H., Najafi, B.F., Racherla, D., Knackstedt, M.A. and Sahimi, M. 2004. 476 Overview of laboratory and modelling studies of carbon dioxide sequestration in coal beds. 477 Industrial and Engineering Chemistry Research, 43(12), pp. 2887-2901.

478 Van Bergen, F., Pagnier, H., Krzystolik, P., 2006. Field experiment of enhanced coalbed methane$479 \mathrm{CO}_{2}$ in the upper Silesian basin of Poland. Environmental Geosciences 13(3),201-224.

480 van Hemert, P., Wolf, K. and Rudolph, E.S.J. 2012. Output gas stream composition from methane 481 saturated coal during injection of nitrogen, carbon dioxide, a nitrogen-carbon dioxide mixture and a 482 hydrogen-carbon dioxide mixture. International Journal of Coal Geology, 89(1), pp. 108-113.

483 Vishal, V., Ranjith, P.G. and Singh, T.N. 2013. $\mathrm{CO}_{2}$ permeability of Indian bituminous coals: 484 Implications for carbon sequestration. International Journal of Coal Geology, 105(1), pp. 36-47.

485 White, C.M., Smith, D.H., Jones, K.L., Goodman, A.L., Jikich, S.A., LaCount, R.B., DuBose, S.B., 486 Ozdemir, E., Morsi, B.I. and Schroeder, K.T. 2005. Sequestration of carbon dioxide in coal with 487 enhanced coalbed methane recovery- A review. Energy and Fuel, 19(3), p. 659-724.

488 Wu, Y-S., Pruess, K. and Persoff, P. (1998). Gas flow in porous media with Klinkenberg effects. 489 Transport in Porous Media, 32, 117-137.

490 Yamaguchi, S., Ohga, K., Fujioka, M., 2006. Field experiment of Japan sequestration in coal seams 491 project (JCOP). Proceedings of the $8^{\text {th }} \mathrm{CO}_{2}$ International Conference on Greenhouse Gas Control 492 Technologies, Trondheim, Norway, June 19C22, 2006.

493 Yu, H., Zhou, L., Guo, W., Cheng, J. and Hu, Q. 2008. Predictions of the adsorption equilibrium of 494 methane/carbon dioxide binary gas on coals using Langmuir and ideal adsorbed solution theory 495 under feed gas conditions. International Journal of Coal Geology, 73(2), pp. 115-129. 
Table 1. Physical and chemical properties of the coal sample.

\begin{tabular}{lrlr}
\hline Moisture (wt\%) & 1.2 & Carbon (\%) & 86.4 \\
Sample diameter $(\mathrm{mm})$ & 70 & Volatile matter (\%) & 9.7 \\
Sample length $(\mathrm{mm})$ & 120 & Fixed carbon (\%) & 84.4 \\
Bulk density $\left(\mathrm{kg} / \mathrm{m}^{3}\right)$ & 1398 & Sulphur (\%) & 0.8 \\
Porosity (-) & 0.05 & Ash (\%) & 4.9 \\
\hline
\end{tabular}




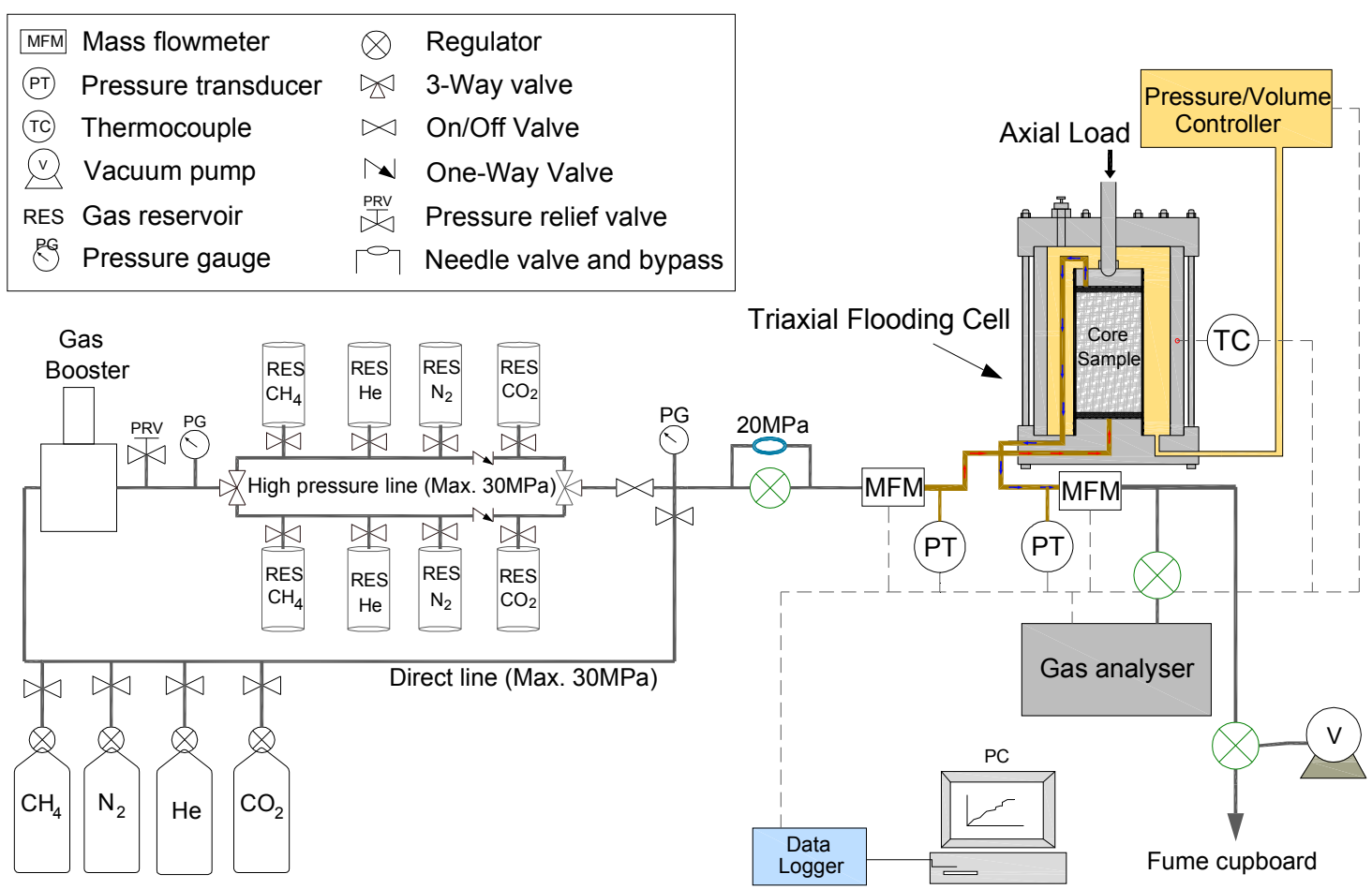

Figure 1. A schematic diagram of the developed laboratory facility (Hadi Mosleh et al., 2017). 
Stage 2- $\mathrm{N}_{2}$ - and $\mathrm{CO}_{2}-E C B M$ experiments

\section{Saturation of the coal sample with $\mathrm{CH}_{4}$}

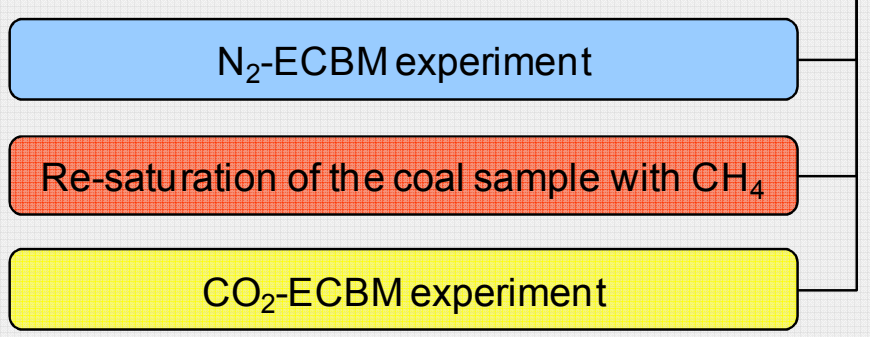

Figure 2. The order of experimental studies carried out. 


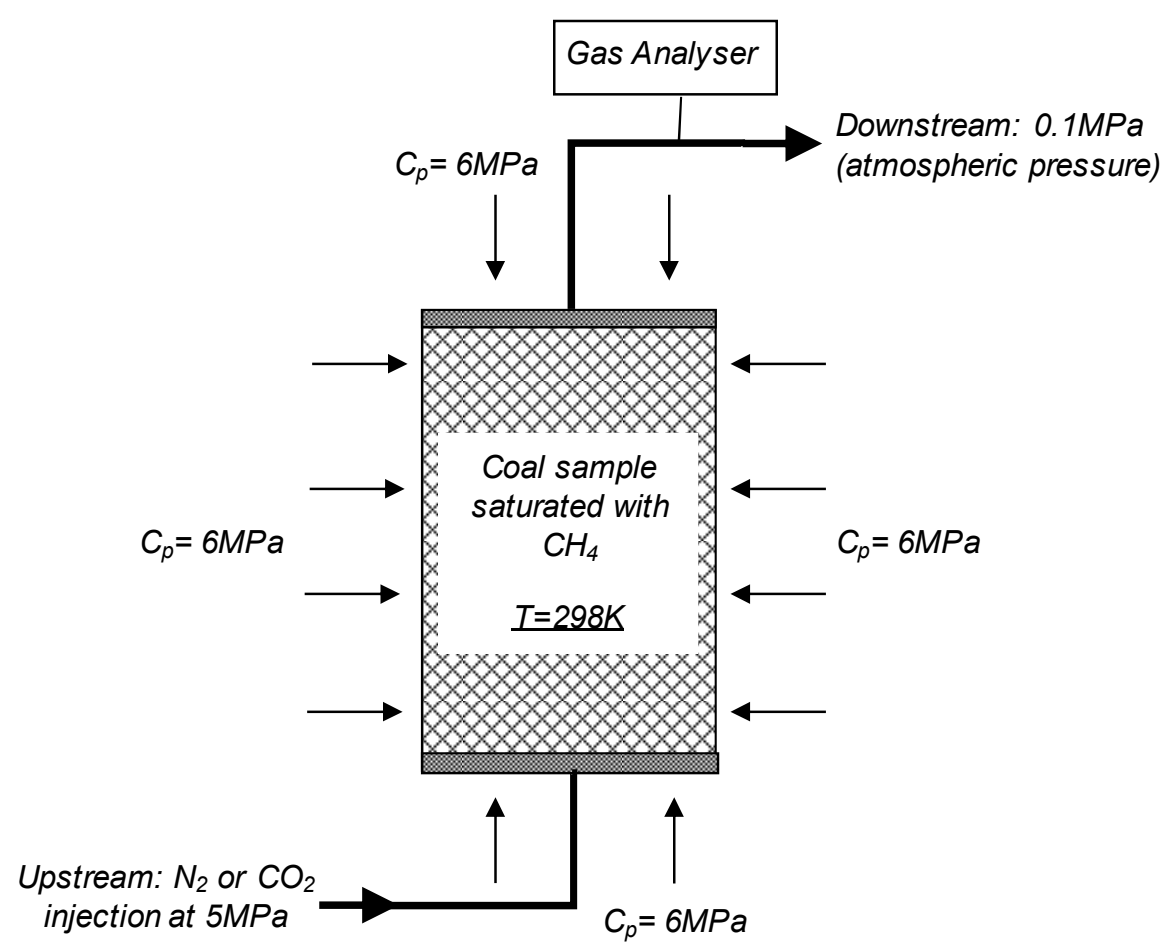

Figure 3. Schematic diagram of the experimental conditions applied for the $\mathrm{N}_{2}$ and $\mathrm{CO}_{2} \mathrm{ECBM}$ experiments, $C_{p}$ is the confining pressure. 


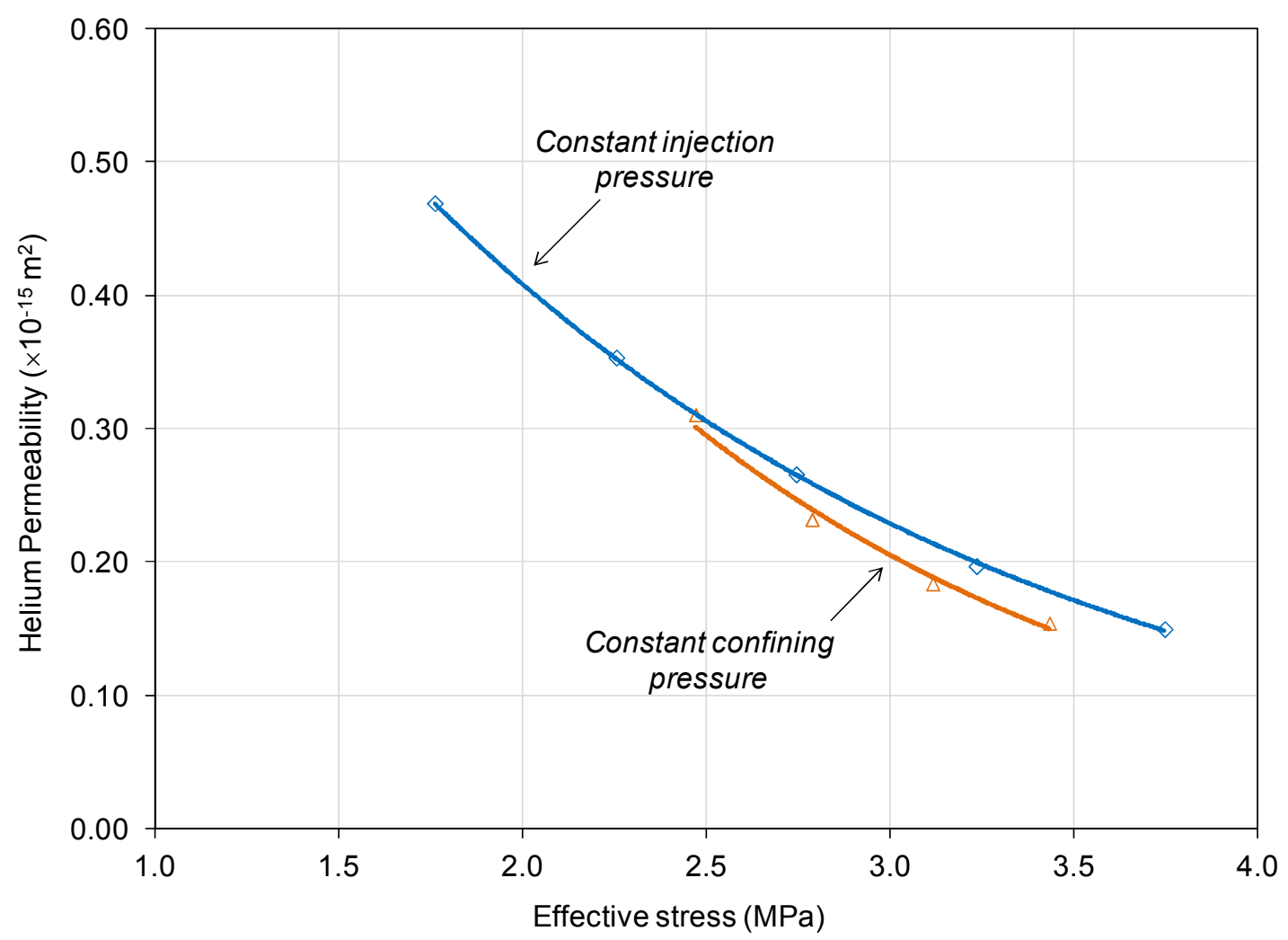

Figure 4a. Variations of the coal permeability to helium with effective stress under constant injection pressure and constant confining pressure. 


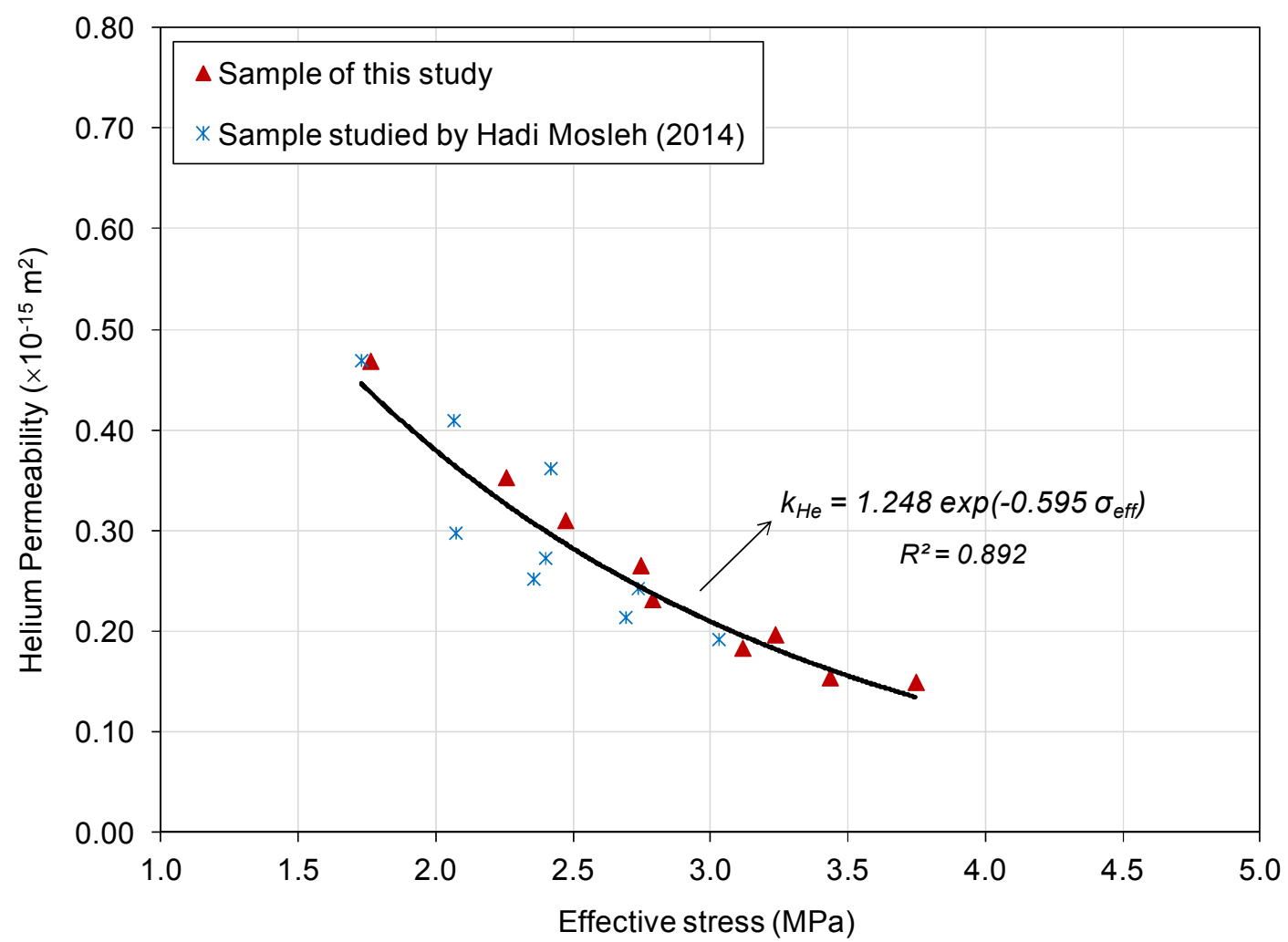

Figure 4b. Variation of coal permeability to helium with effective stress for the sample of this study and a sister sample obtained from same block of coal (Hadi Mosleh, 2014). 


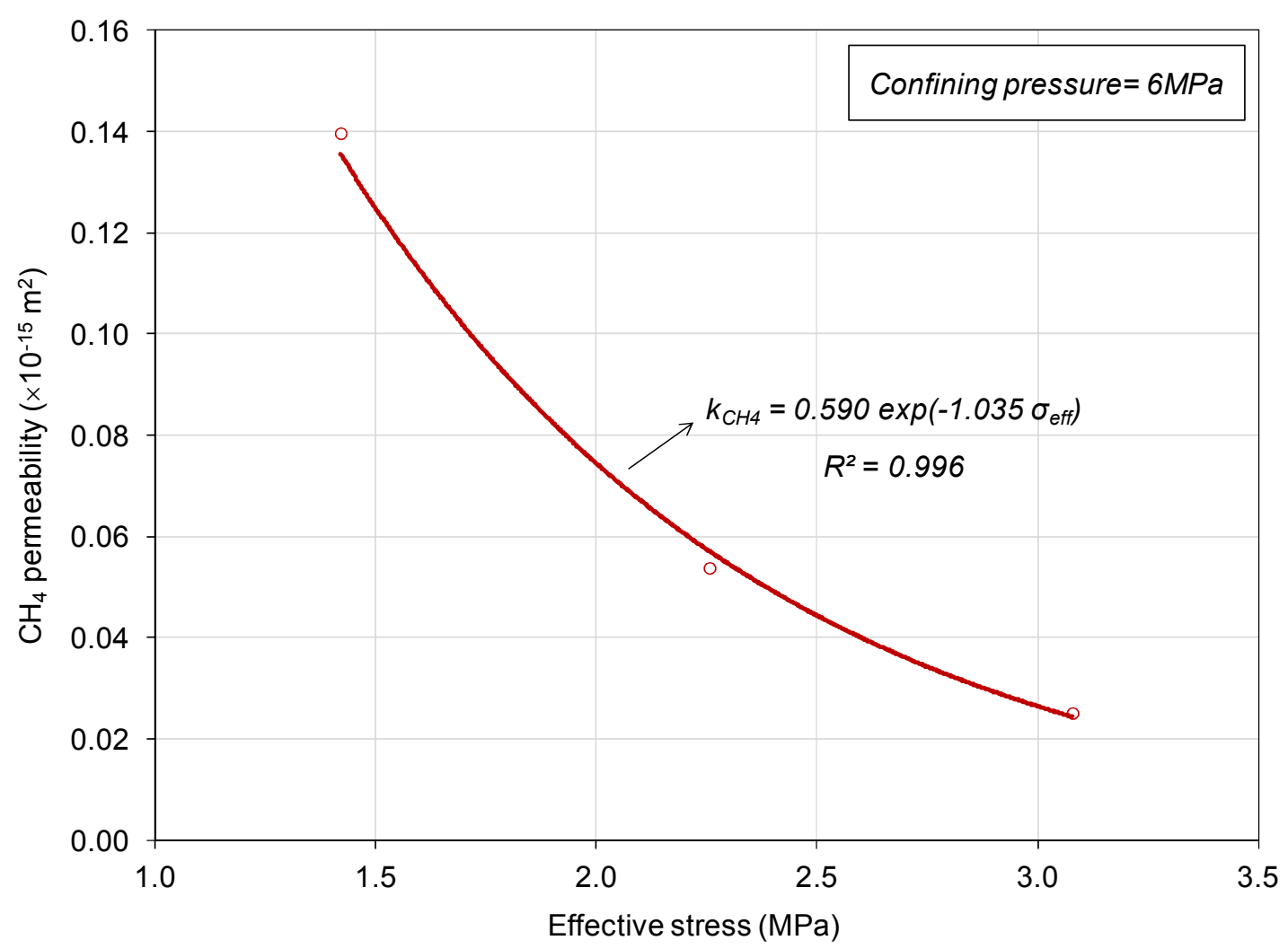

Figure 5. The relationship between permeability of the coal sample to $\mathrm{CH}_{4}$ and effective stress. 


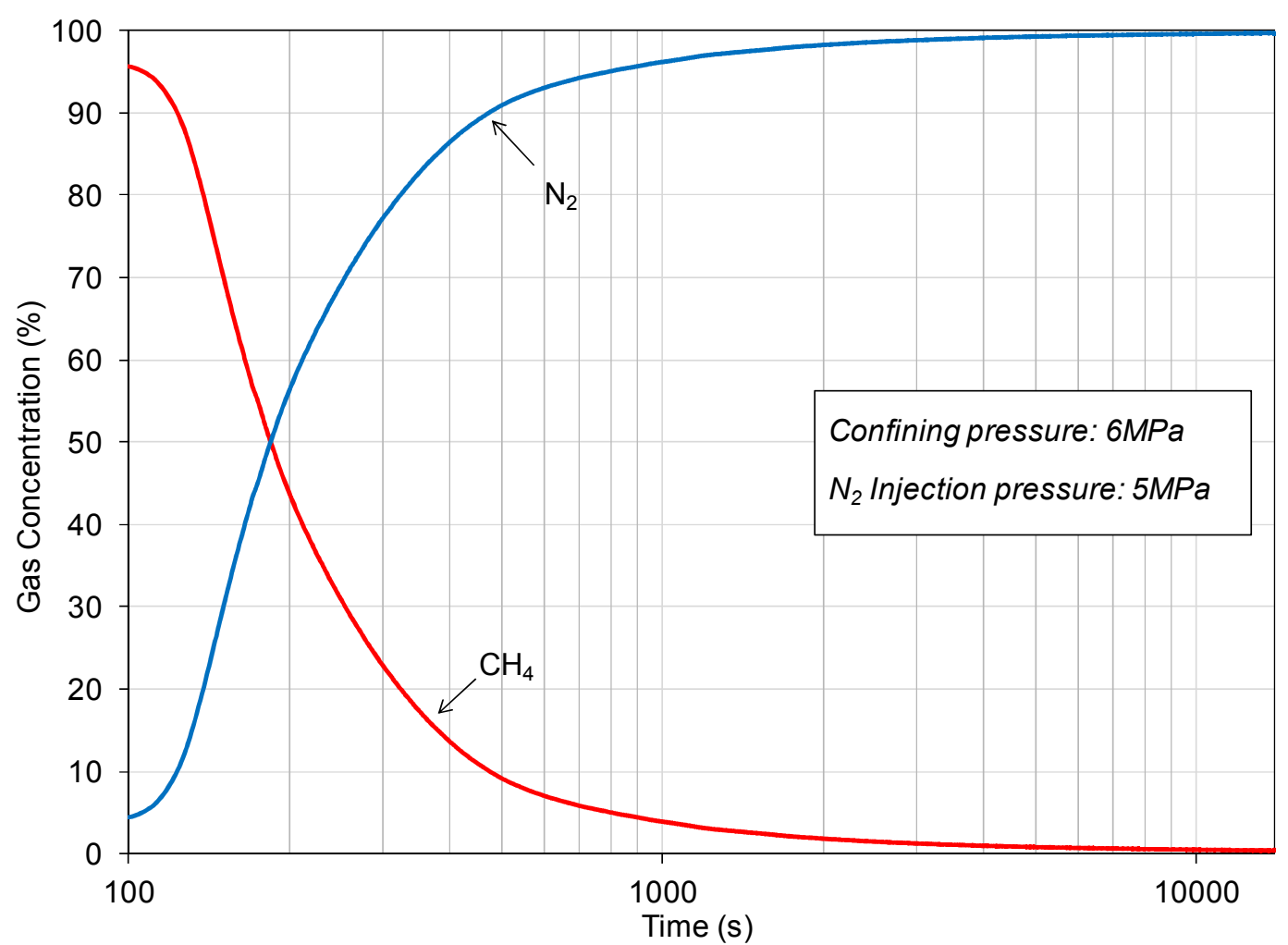

Figure 6. The composition of the production gas with time during the $\mathrm{N}_{2}$ experiment. 


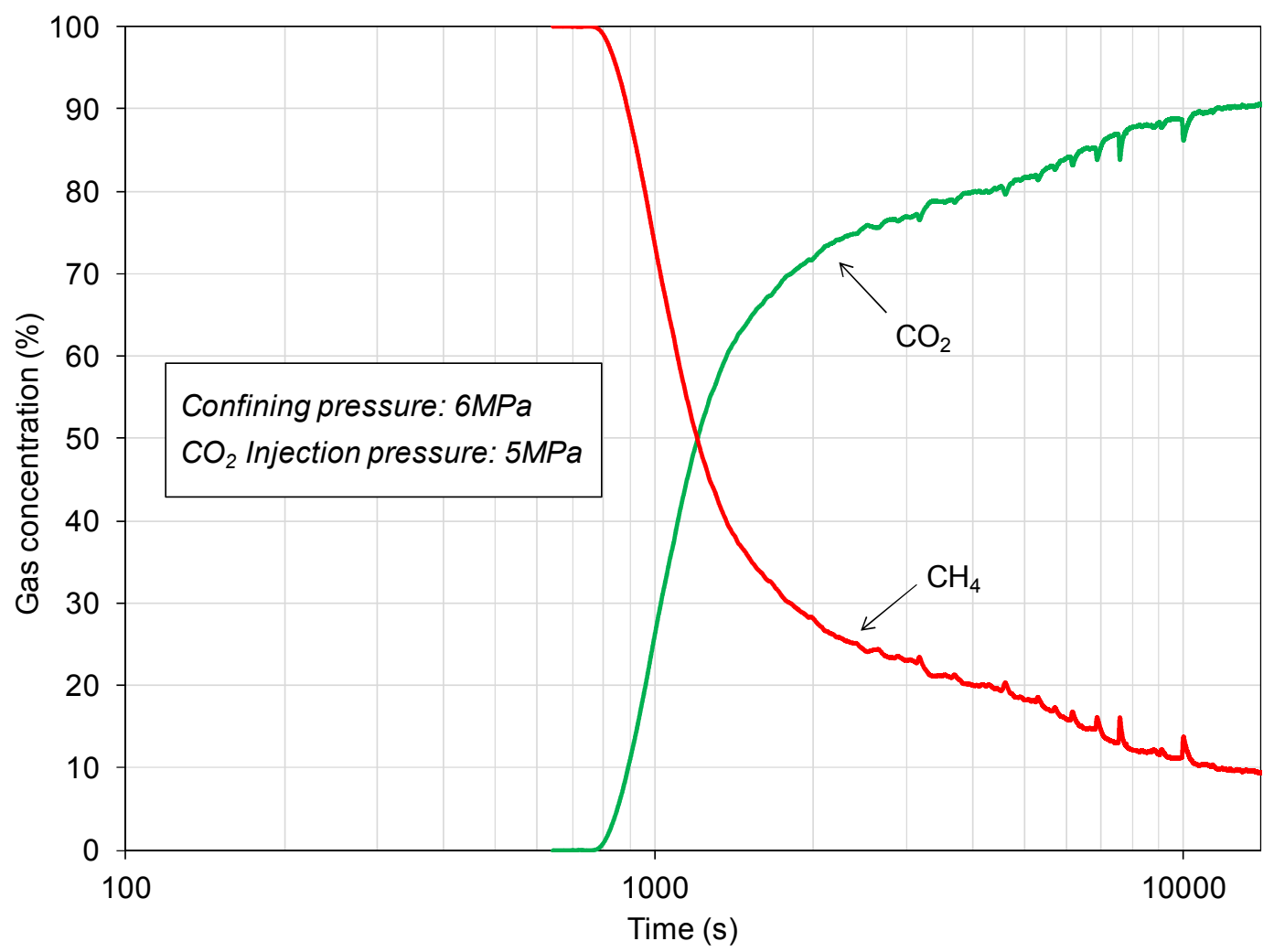

Figure 7. The composition of the production gas with time during the $\mathrm{CO}_{2}$ experiment. 


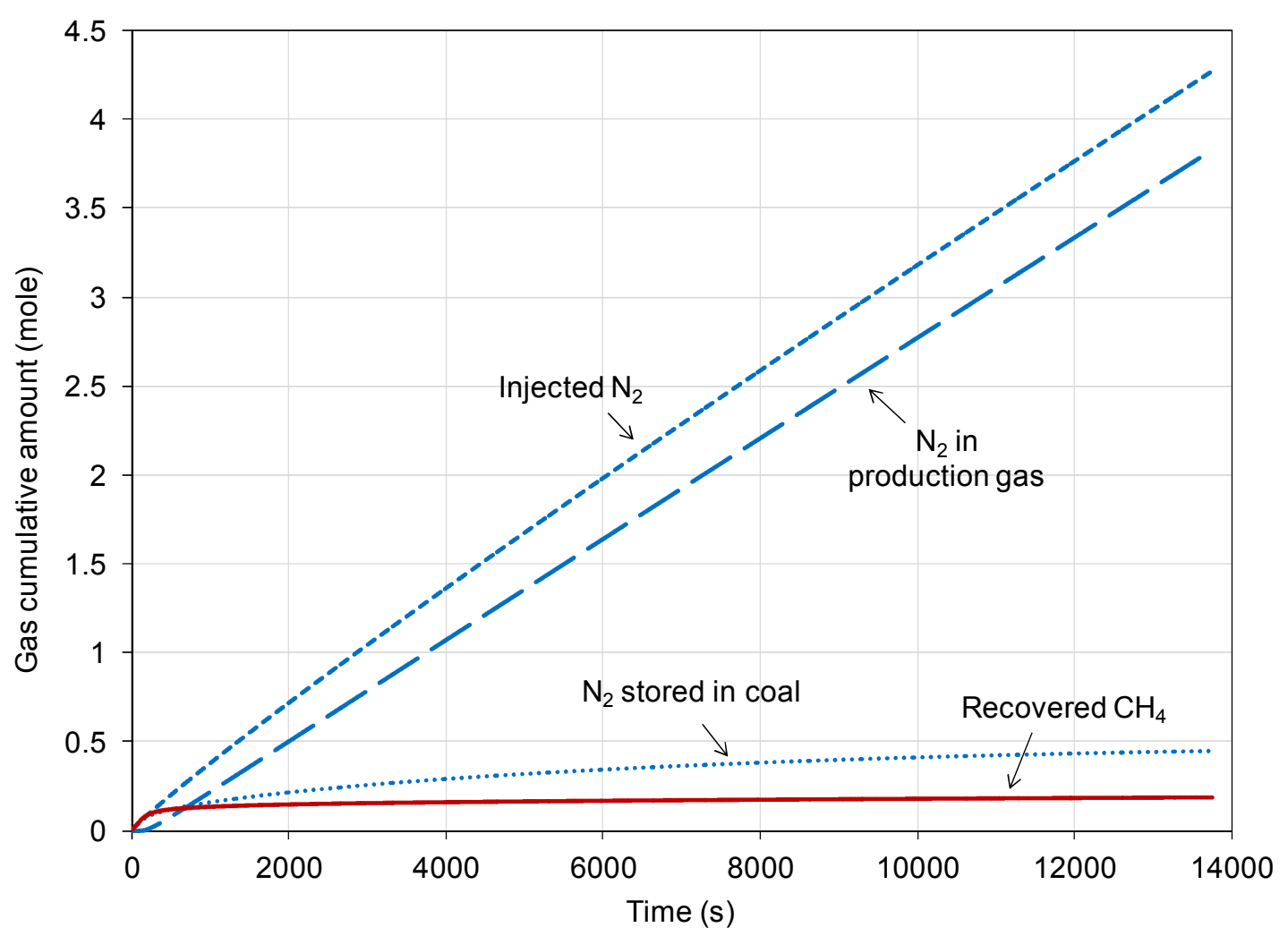

Figure 8. Cumulative amounts of $\mathrm{N}_{2}$ injected, recovered and stored with time during the $\mathrm{N}_{2}$-ECBM experiment. 


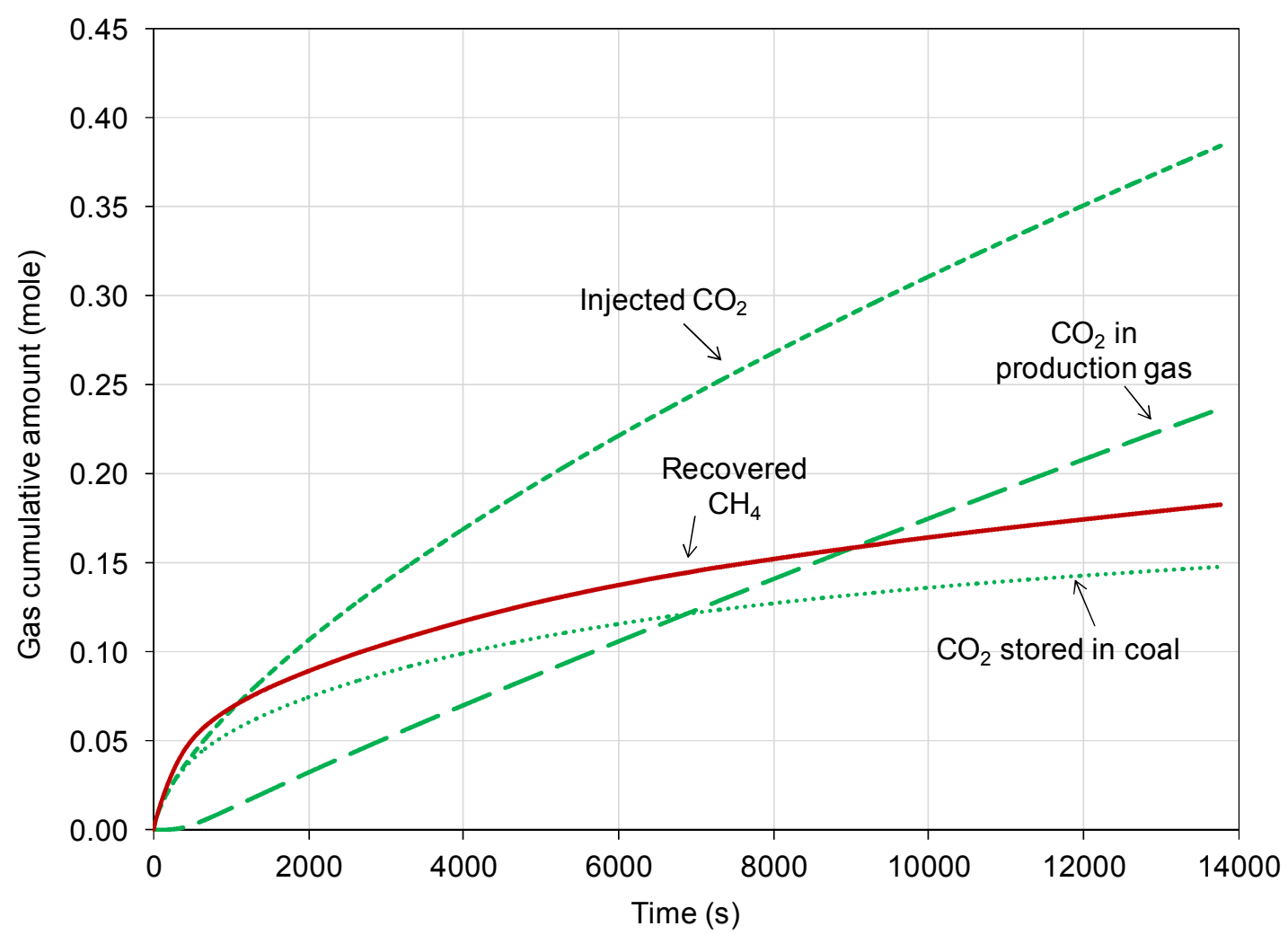

Figure 9. Cumulative amounts of $\mathrm{CO}_{2}$ injected, recovered and stored with time during the $\mathrm{CO}_{2}$ ECBM experiments. 


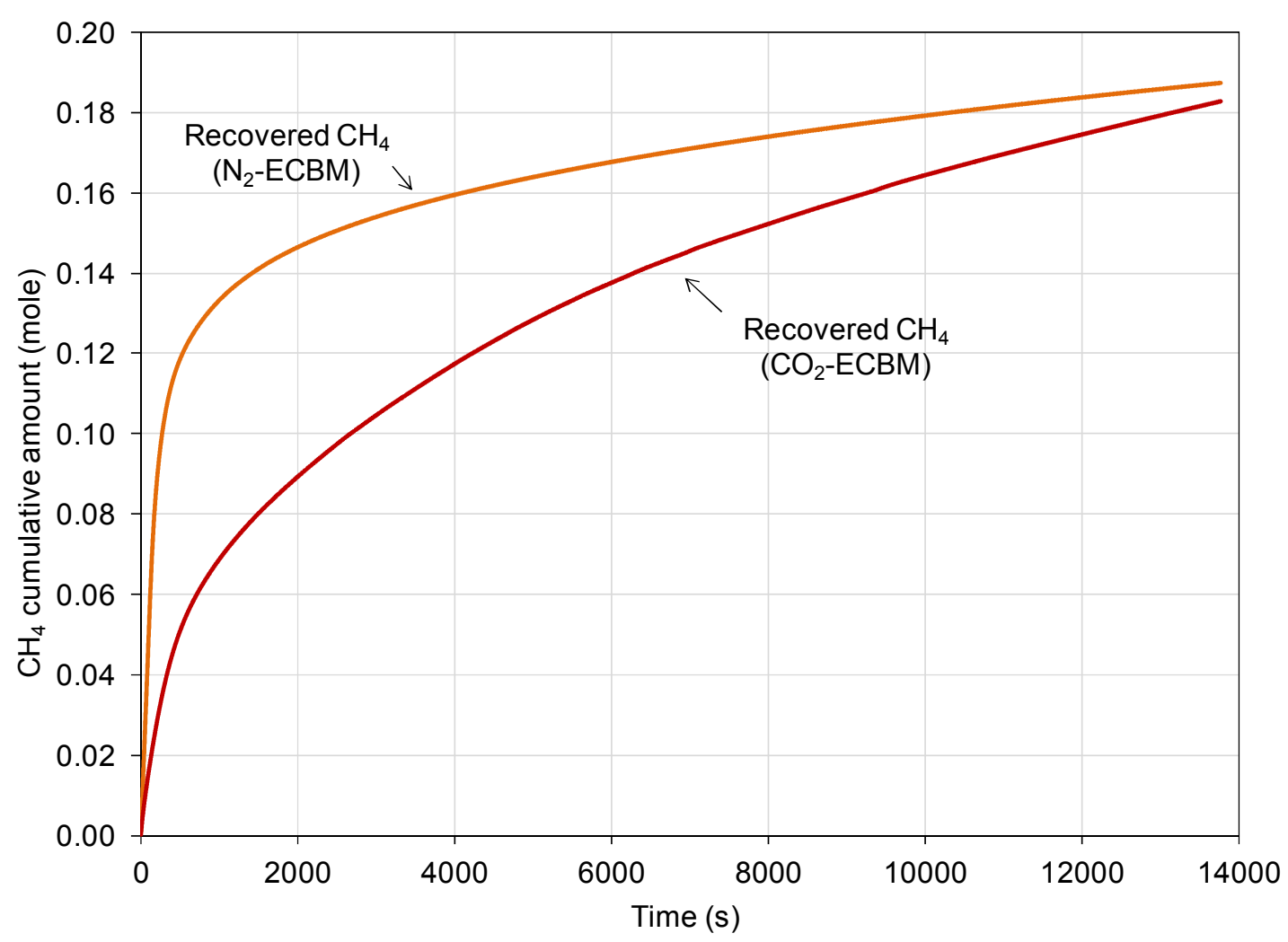

Figure 10. Cumulative amounts of $\mathrm{CH}_{4}$ recovery during the $\mathrm{N}_{2}-\mathrm{ECBM}$ and $\mathrm{CO}_{2}$-ECBM experiments. 


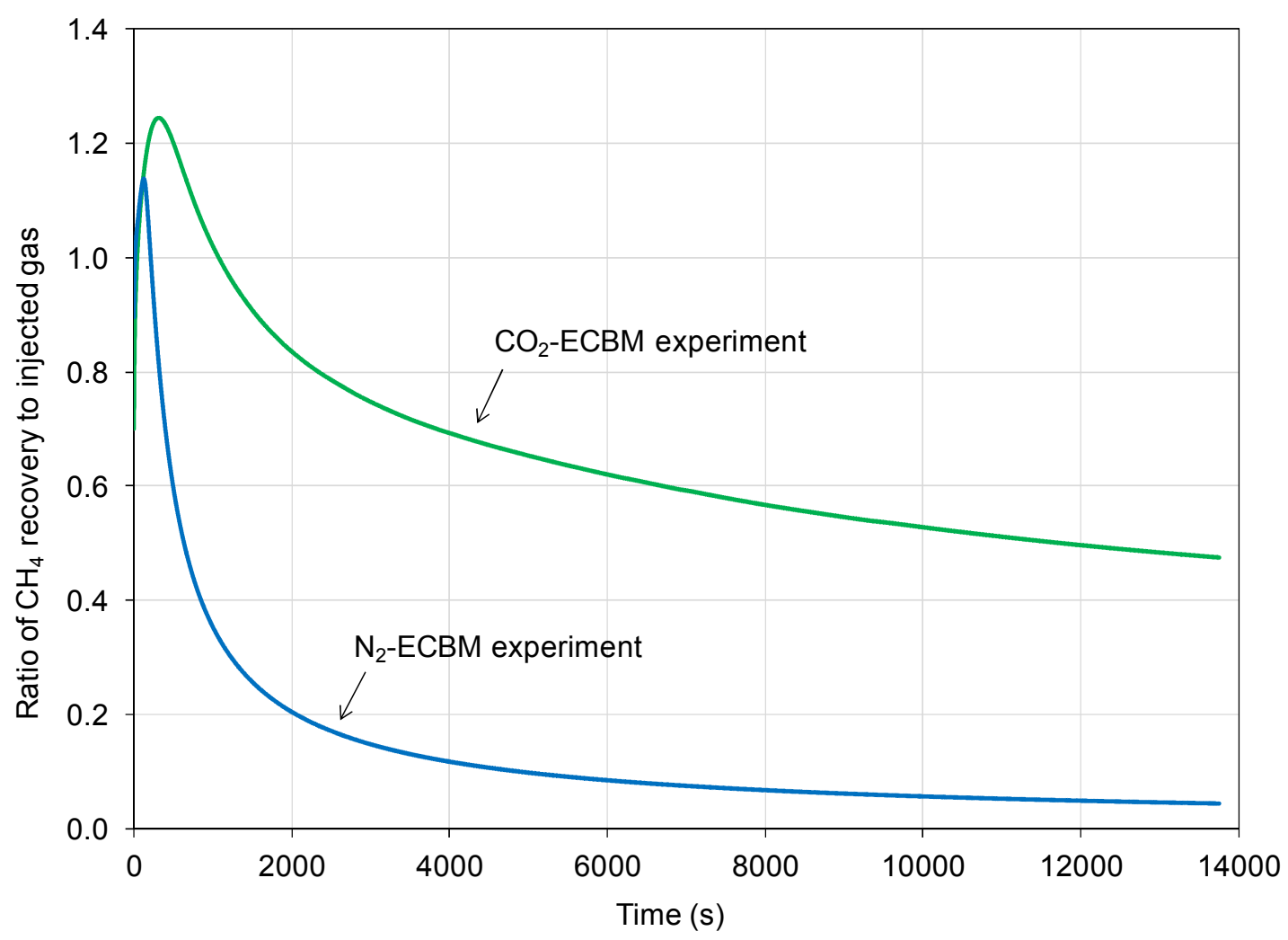

Figure 11. The ratio of $\mathrm{CH}_{4}$ recovery to injected gas and its variation with time. 


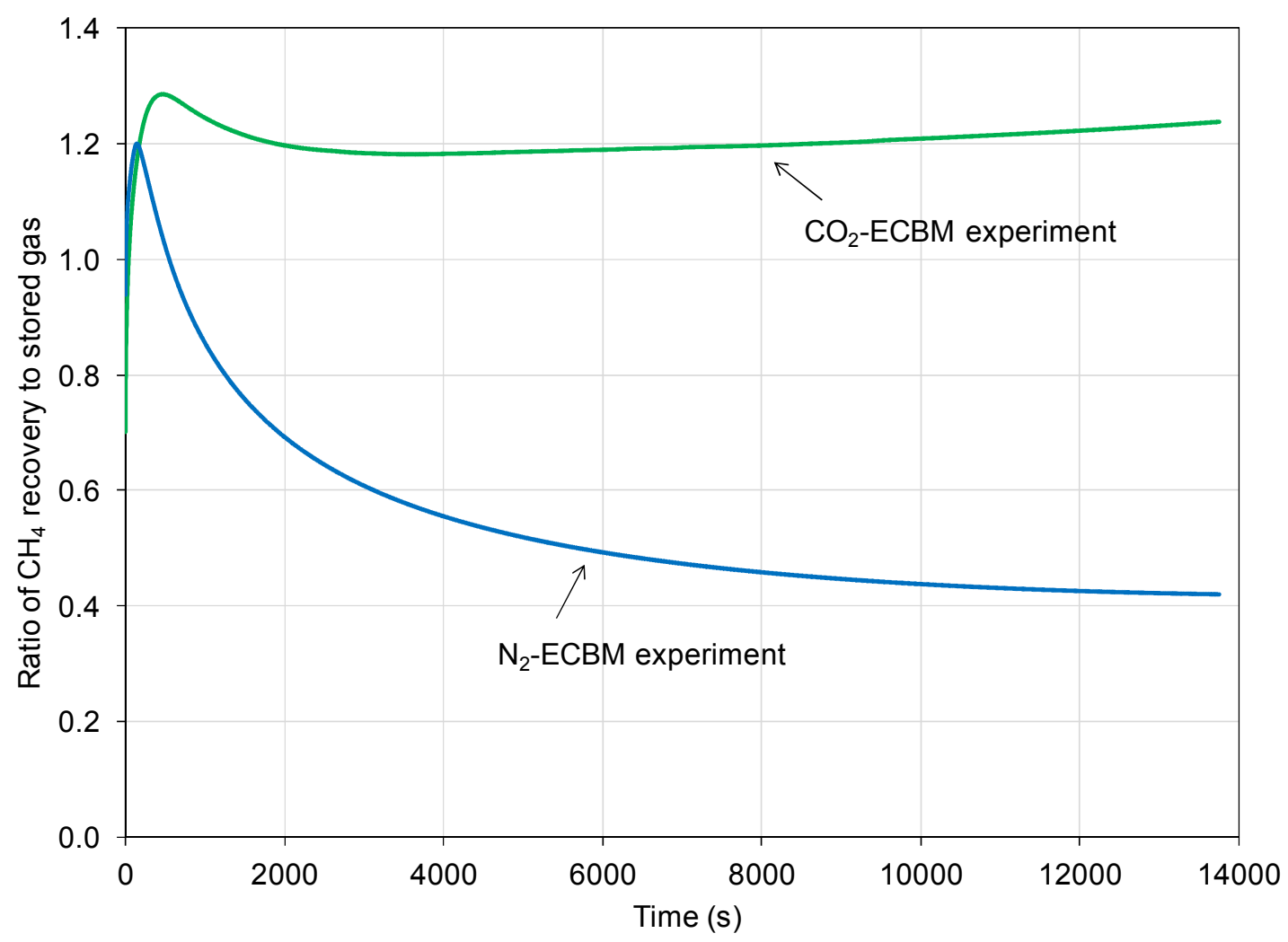

Figure 12. The ratio of $\mathrm{CH}_{4}$ recovery to stored gas and its variation with time. 